\title{
Gissel Packing and "Good Faith Doubt": The Gestalt of Required Recognition of Unions under the NLRA
}

\author{
Andrea Svanoe Christensen $\dagger$ \\ Thomas G. S. Christensenf
}

\begin{abstract}
Gestalt psychology... Psychology based on the theory that physical, psychological, and biological events do not occur through the summation of separate elements, as sensations or reflexes, but through formed patterns of these, integrated units which function singly or in interrelation; configurationism. Each of these patterns is called a Gestalt ....

Webster's New Collegiate Dictionary When in doubt, play trump.
\end{abstract}

Author unknown

Several years ago, the authors of this paper surveyed the place of motive and intent in the determination of what acts constitute forbidden discrimination under the terms of sections $8(a)(3)$ and $8(b)(2)$ of the National Labor Relations Act. ${ }^{1}$ Writing a scholarly piece for a scholarly journal induces strange reactions in the minds of those so brave or so foolish as to undertake such work. In the instance just referred to, it led to an introduction which immediately set forth one of the magic incantations of the legal trade, the full latin phrasing of the maxim usually shorthanded as mens rea. ${ }^{2}$ An independent survey conducted thereafter revealed that, because of that quotation, ninety per cent of the readers of the learned journal involved did not read beyond the first line of the article; indeed, seventy-five per cent did not read even the first line. ${ }^{3}$ Accordingly, it was determined that any sequel

$\dagger$ Member of the New York Bar. B.A. 1960, Vassar College; LL.B. 1966, New York University.

$\ddagger$ Professor of Law, New York University and Executive Director, New York University Institute of Labor Relations. B.A. 1945, J.D. 1947, University of Iowa.

1 Christensen \& Svanoe, Motive and Intent in the Commission of Unfair Labor Practices: The Supreme Court and the Fictive Formality, 77 YaLE L.J. 1269 (1968).

2 Id. at 1269. Actus non facit reum nisi mens sit rea.

3 Private poll conducted by the authors based upon a representative $(1 / 10$ of $1 \%$ of individuals observed browsing through the periodical department of a bar association library on June 21, 1969 between the hours of 11:00 a.m. to 11:30 a.m.) sampling. 
to the aforementioned study should stress-at least in its opening paragraphs-either sex or some form of suitably sophisticated and currently popular approach such as applied psychology in the hope of luring the reader to ignore an entirely natural urge to turn, instead, to pages that would hopefully offer succor to a current problem with a paying client. Sex, unfortunately, proved impossible to utilize in this regard; framing our inquiry in terms of defining the "Gestalt" of required recognition offered the most attractive alternative.

While partially tongue in cheek, the above quotations and these opening remarks are, in candor, an effort to interest the bar (apart from the labor law oriented segment of our ranks) with a problem whose determination has had and will continue to have enormous impact upon our society. The assassination of Martin Luther King occurred in the context of a struggle over the recognition of a collective bargaining representative. While that struggle was not, under present law, controlled by the mandates and sanctions of the federal law under examination here, it furnishes a grim example of the deep social conflicts subsumed in the problem of when and in what circumstances an employee organization must be accorded legal recognition as an exclusive bargaining representative. Solutions, if any, found in the "private sector" of American enterprise governed by the National Labor Relations Act will necessarily provide essential guidance to the resolution of these problems in the "public sector."

As an initial premise it must be recognized that "private sector" law has established and codified one solution to representational disputes which is not only utilized by the overwhelming majority of employers and unions subject to the NLRA but is relatively uncomplicated in its basic premises. This machinery is set forth in section 9 of the Act ${ }^{4}$ which allows a secret ballot election to be held under the auspices of the National Labor Relations Board on petition of employees, claimant representatives or employers to determine "questions of representation" of employees in a unit appropriate for collective bargaining. While section 9 also affords detailed instructions as to many of the issues which can and do arise in the processing of such petitions and the conduct of such elections, the primary thrust of the law is simple and clear; the question of which union, if any, is to be the exclusive bargaining representative shall be determined by the registered choice of a majority of eligible employees who vote by secret ballot.

Had Congress left the matter there-that designation of the exclusive

429 U.S.C. § 159 (1964). 
bargaining agent can be determined only by the election procedures of section 9-the problems with which this paper is concerned would not exist. But Congress did not content itself, in the original passage of the Wagner Act or in subsequent ame-1dments to that statute, with one such simple approach. Congress has consistently indicated since 1935, albeit with varying enthusiasm for specific alternatives, that recognition of a union as exclusive representative can be and must be accorded in other circumstances, that is, where there is a "refusal to bargain" contrary to the mandate of sections $8(a)(5)$ and $8(b)(3) .{ }^{5}$

Congress, in enacting these sections, was remarkably terse in its statement of the commands contained therein. Perhaps that reluctance to issue other than generalized control was fortunate; where the Congress has chosen to define an unfair labor practice in detailed terms, the result has not necessarily produced clarity or unambiguous standards for interpretation and administration. In any event, Congress, in these sections, chose to be succinct. Section $8(a)(5)$ requires an employer not "to refuse to bargain collectively with the representatives of his employees, subject to the provisions of Section 9(a)."B Section 8(b)(3) imposes a like obligation in almost the same words; a union may not "refuse to bargain collectively with an employer, provided it is the representative of his employees subject to the provisions of Section 9(a)."7 It is true that an additional provision, section 8(d), fleshes out these bare legislative bones by stating various duties encompassed by the obligation thus described. ${ }^{8}$ The thrust and content of the latter section, however, is almost exclusively directed to what comprises compliance with the statutory duty to bargain after the status of the collective representative has been ascertained. Other than the noted and quoted cross-references to the provisions of section 9 , no explicit congressional instruction is set forth in either section $8(\mathrm{a})(5)$ or section $8(\mathrm{~b})(3)$ as to when, and under what circumstances, the obligation "to bargain collectively" commences.

Where the Board, under the provisions and procedures of section 9 , certifies that a certain labor organization is the exclusive represen-

$\sigma 29$ U.S.C. § 158(a)(5) (1964); 29 U.S.C. $\$ 158(b)(3)$ (1964).

629 U.S.C. \& 158(a)(5) (1964).

729 U.S.C. \& 158(b)(3) (1964).

829 U.S.C. \& 158(d) (1964). Under this section the obligation to "bargain collectively" is defined as "the performance of the mutual obligation of the employer and the representative of the employees to meet at reasonable times and confer in good faith with respect to wages, hours, and other terms and conditions of employment, or the negotiation of an agreement, or any question arising thereunder, and the execution of a written contract incorporating any agreement reached if requested by either party, but such obligation does not compel either party to agree to a proposal or require the making of a concession." 
tative of employees in a defined unit for bargaining, the question of whether the employer, prior to the date of certification, has looked on the union as the real, probable or not-to-be-believed choice of his employees is a moot issue. The certification looks to the future and is not concerned with past attitudes. ${ }^{9}$ This is not to say that the motivations, intentions and states of mind of the affected parties are not inextricably concerned with many aspects of the interpretation and enforcement of the duty to bargain collectively. Thus, the mandate of section $8(\mathrm{~d})$ that the parties must "confer in good faith" rightly or wrongly literally requires that some inquiry into the states of mind of the conferring parties be made. That issue has been extensively (if not exhaustively) examined by others. ${ }^{10} \mathrm{It}$ is an inquiry, however, entirely separate from the issue of what role, if any, motivation plays in the determination of when and where the obligation to bargain legally commences absent a section 9 election. It is as to the latter question, that is, whether the subjective intent of the parties should or, indeed, can be examined in order to determine whether a collective bargaining relationship has been legally established, that this present inquiry is directed.

The question is one which has been tangentially, if not directly, examined in what amounts to a plethora of legal briefs, Board and court opinions, and learned commentary in the journals of the trade - particularly in the past decade. ${ }^{11}$ Some apologia for adding to this

9 Section $9(c)(1)$, in predicating the circumstances requisite for a certification, speaks in terms of a Board finding that there is "reasonable cause to believe that a question [concerning] representation . . exists." As will be discussed hereinafter, this provision (at least in current Board interpretation) does not negate the possibility of overlapping $\S 9$ and $\S 8(a)(5)$ actions. This overlapping, however, is most apparent when there is no certification resulting from the electoral process. Indeed, while it is theoretically possible for a union recipient of a certification to contend that recognition should have been accorded and was legally due at an earlier date, the practicalities of such a situation militate against such a claim. The certified union, in such circumstances, is invariably more concerned with effective usage of its formally established status than with processing a pragmatically "stale" claim relating only to what "might have been."

10 The basic survey of this area has been and still is, of course, that of Professor Archibald Cox, The Duty to Bargain in Good Faith, 71 Harv. L. Rev. 1401 (1958). A listing of the myriad of other essays as to the meaning of "good faith bargaining" would exhaust the patience of the authors of this article, the editors of the Review and the printers who are called upon to set such material in type.

11 See, e.g., Comment, Union Authorization Cards, 75 Yale L.J. 805 (1966); Comment, Standards Established for Issuance of Bargaining Orders Based on Authorization Cards, 1969 Duke L.J. 1075; Comment, The Reliability of Card Checks in Establishing Collective Bargaining Representative Status, 37 FordHAM L. REv. 648 (1969); Lesnik, Establishment of Bargaining Rights Without an NLRB Election, 65 MICH. L. REv. 851 (1967); Wolkinson, The Remedial Efficacy of NLRB Remedies in Joy Silk Cases, 55 CORNELL L. REV. 1 (1969); Sheinkman, Recognition of Unions Through Authorization Cards, 3 GA. L. REv. 319 (1969); Browne, Obligation to Bargain on Basis of Card Majority, 3 GA. L. REv. 334 (1969). 
mass of material is thus necessary, if only to salve the consciences of the authors of this paper. The justification is basically dual in nature. Most of what has been written or litigated in the area under inquiry here has been devoted to what might be termed the "War of the Authorization Card"- - a battle where the contesting forces have, basically, argued the issue of what quantum of evidence of union adherence by employees is requisite to the duty to recognize that union as an exclusive representative in an appropriate bargaining unit. More importantly, in the past term, the Supreme Court issued an opinion which, though unanimous and lengthy, raises more issues than it answers. These acknowledged but unanswered issues, in many instances, relate directly to the question of the place of motive in the determination of when and under what circumstances an employer is legally obligated to recognize a union which has not achieved the status of a certified representative of its employees.

In the Supreme Court decision adverted to, NLRB v. Gissel Packing Company, ${ }^{12}$ at least one legal principle was firmly and (absent congressional veto by further legislative action) finally nailed into place. As stated by the Court, "[t] he first issue facing us is whether a union can establish a bargaining obligation by means other than a Board election and whether the validity of alternate routes to majority status, such as [authorization] cards, was affected by the 1947 TaftHartley amendments." 13 The answer by the Court was, predictably, that alternate routes are available, that is, that even though in a given case a union has not been certified by the Board as exclusive representative under section 9 procedures, it may still be legally entitled to recognition. The basic support for a contrary view was founded primarily upon a presumed congressional intent in the 1947 amendments to the Act essentially to exclude all alternative methods (other than voluntary recognition) for obtaining the status of exclusive representative other than by the secret ballot election. ${ }^{14}$ Those amendments, through the vehicle of the Taft-Hartley Act did, of course, indicate a congressional preference for the secret ballot route to establishment as a representative. Not only were certifications (as contrasted with other findings of majority support) made dependent upon use

12395 U.S. 575 (1969).

13 Id. at 595-6.

14 This view was summarized in an amicus curiae brief presented to the Court in Gissel (brief of American Retail Federation, p. 13) as follows: "Congress intended to grant employers an absolute right to an election to determine questions of representation and preclude the use of authorization cards for this purpose. Only when no question of representation existed, or when an election under Section 9(c) was rendered impossible, therefore, would a card-based bargaining order be warranted" after passage of the 1947 changes in the statute. 
of section 9 election procedures, but employers were given far greater access to such procedures when confronted with demands for recognition. ${ }^{15}$ As the Court detailed at some length in Gissel, however, the legislative history of the 1947 amendments discloses a congressional rejection of provisions which would have explicitly required that the obligation to bargain collectively be dependent upon certification after a secret ballot election under section 9 or upon some other, voluntary recognition. ${ }^{16}$ It was not surprising, accordingly, that the Court concluded that "the 1947 amendments did not restrict an employer's duty to bargain under $\S 8(a)(5)$ solely to those unions whose representative status is certified after a Board election."17

All of which, however, is merely prologue to the far more difficult question as to when the obligation to bargain arises where section 9 procedures are not utilized. This question cannot be relegated to obscurity on the ground that, as the Court points out, secret ballot elections are, numerically, the normal route to recognition. Despite the fact that in 1967 the Board conducted 8,116 elections and "only" issued 157 orders to bargain based upon an authorization card majority, the Court itself acknowledged that this represented a "dramatic increase over previous years." 18 Nor is the number of actual bargaining orders necessarily indicative of the full force of the legal controls involved; no measure exists as to the number of instances in which bargaining rights were accorded without litigation on advice of counsel-advice which could or could not have been impelled by the thrust of the reported cases. One might well doubt, in this regard, that the number of judicial decisions in paternity suits represents a true guide to the number of what are colloquially known as "shotgun" marriages.

It was to the question, then, of what limits are to be applied where, in the absence of a valid section 9 election, recognition of a union as exclusive bargaining representative is to be required, that the Court

15 As the Court noted in Gissel:

Under the Wagner Act, which did not prescribe who would file election petitions, the Board had ruled that an employer could seek an election only when two unions presented conflicting bargaining requests on the ground that if he were given the same election petition rights as the union, he could interrupt union drives by demanding an election before the union had obtained majority status. The 1947 amendments resolved the difficulty by providing that an employer could seek an election only after he had been requested to bargain.

See H.R. Rep. No. 245, 80th Cong., 1st Sess., 35 (1947). 395 U.S. at 599 n.15.

16 Indeed, a proposed House bill which would have permitted the Board to find a refusal-to-bargain violation only where the union seeking bargaining rights was "currently recognized by the employer or certified as such [through an election] under Section 9 (Sec. 8(2)(5) of H.R. 3020, 80th Cong., Ist Sess. (1947))" was expressly rejected in Conference. H.R. CoNF. REP. No. 510, 80th Cong., 1st Sess. 41 (1947).

17395 U.S. at 600.

$18 \mathrm{Id}$. at $596 \mathrm{n} .7$. 
addressed itself in Gissel. What the Court decided and, more importantly, what it did not decide is more easily understandable by reviewing, first, the legal background and, second, the factual context in which the decision was rendered.

\section{The Basic Law: Pre-Gissel}

In the period 1935 to 1947 , section 9 of the NLRA allowed the Board to resolve a question of claimed majority support in an appropriate bargaining unit by an investigation followed by "a secret ballot of employees, or . . . any other suitable method" of ascertaining such representational status. ${ }^{19}$ During the same period, the Supreme Court issued its decision in Franks Bros. v. NLRB. ${ }^{20}$ In that case, a union established a "majority" on the basis of authorization cards which was, by subsequent employer unfair labor practices, eroded to the extent that it was not possible to maintain that the claimant union, at the effective date of the Board order, possessed majority support demonstrable by any means, secret ballot or otherwise. The Board, nonetheless, directed the employer to bargain collectively with the union. ${ }^{21}$ The Court affirmed the order to bargain commenting that:

Out of its wide experience, the Board many times has expressed the view that an unlawful refusal of an employer to bargain collectively with its employees' chosen representatives disrupts the employees' morale, deters their organizational activities, and discourages their membership in unions. The Board's study of this problem has led it to conclude that, for these reasons, a requirement that union membership be kept intact during delays incident to hearings would result in permitting employers to profit from their own wrongful refusal to bargain.22

To this, the Court added:

The Board might well think that, were it not to adopt this type of remedy, but instead order elections upon every claim that a shift in union membership had occurred during proceedings occasioned by an employer's wrongful refusal to bargain, recalcitrant employers might be able by continued

1929 U.S.C. § 159(c) (1995); see also NLRB v. Dahlstrom Metallic Door Co., 112 F.2d 756 (2d Cir. 1940); Denver Automobile Dealers Ass'n, 10 N.L.R.B. 1173 (1939); Century Mills, Inc., 5 N.L.R.B. 807 (1938).

20321 U.S. 702 (1944).

21 In re Franks Bros., 44 N.L.R.B. 898 (1942). The Board's order was enforced by the First Circuit, 137 F.2d 989 (1st Cir. 1943).

22321 U.S. at 704. 
opposition to union membership indefinitely to postpone performance of their statutory obligation. ${ }^{23}$

The Court's affirmance of the Board's order to bargain clearly predicated certain conclusions. First, a majority status (at least before the 1947 amendments) could be established by means (and as of a preceding date) other than a secret ballot election. Second, if such a "majority" is destroyed by employer unfair labor practices, the Board may nonetheless direct installation of a union very probably presently possessing less than a majority status if only to forestall employer utilization of its own unfair labor practices to its own profit.

Rightly or wrongly, these basic premises of Franks Bros. survived, in judicial interpretation, the Taft-Hartley amendments which eliminated Board use of "any other suitable method" apart from a secret ballot election as a basis for certification. Indeed, in 1950, as shall be discussed in more detail hereinafter, these premises were expanded into what has become known as the Joy Silk doctrine, ${ }^{24}$ a doctrine which expanded upon the Franks Bros. propositions that (a) a majority status may be established legally without use of a secret ballot election and that (b) an employer may be required to recognize such a "majority" choice (without assurance of its existence at the time bargaining is directed) because of the impact of his anti-union actions.

Both the foregoing premises were, in the period which followed Franks Bros., under heavy attack.25 They nonetheless survived and, indeed, grew in importance if not clarity of statement. They, further, formed the basis for the review of required recognition which the Court conducted in Gissel.

NLRB v. Gissel Packing Company ${ }^{26}$ represents the Supreme Court's determination of four separate controversies involving compulsory union recognition, cases which were individually determined at both the Board and the circuit court level but were treated in one opinion by the Court. ${ }^{27}$ Three separate cases arising out of unsuccessful union organizing drives at Heck's, Inc., General Steel Products, and the Sinclair Company, were consolidated by the Supreme Court for pur-

23 Id. at 705.

24 Joy Silk Mills v. NLRB, 185 F.2d 732 (D.C. Cir. 1950).

25 See note 11 supra.

26395 U.S. 575 (1969).

27 Gissel Packing Co., Heck's, Inc., and General Steel Prods., Inc., were consolidated following three separate decisions of the Fourth Circuit, denying enforcement of the Board's bargaining order. NLRB v. Gissel Packing Co., 398 F.2d 336 (4th Cir. 1968); NLRB v. Heck's, Inc., 398 F.2d 337 (4th Cir. 1968); General Steel Prods., Inc. v. NLRB, 398 F.2d 339 (4th Cir. 1968). The fourth case, NLRB v. Sinclair Co., 397 F.2d 157 (1st Cir. 1968) challenged the First Circuit's enforcement of the Board bargaining order. 
poses of decision with a fourth organizational attempt which had taken place at Gissel Packing. It can be fairly assumed that the Court regarded all four disputes as sufficiently applicable in factual context and subject to the same legal conclusions as to allow such group disposition; indeed, Chief Justice Warren at the outset justified such consolidation by stressing the "similar, uncomplicated factual settings" 28 of three of the lower court decisions and singling out only the additional first amendment problems posed in Sivclair.

While thus combined for decisional purposes, the four cases jointly disposed of are not identical but, rather, comprise a spectrum of representational disputes. In Gissel, ${ }^{29}$ the title case, the union seeking recognition did not, at any time pertinent to the dispute, attempt to use the election procedures set forth in section 9 (c) of the Act. In Heck's, Inc., ${ }^{30}$ an election was petitioned for by the organizing union but was never held. In both General Steel ${ }^{31}$ and Sinclair ${ }^{32}$ a representation petition was filed, followed by an election under Board auspices in which the union failed to secure a majority of the eligible, voting employees. The election results in both instances were set aside by the Board. In all four cases, the employer was held to have violated one or more sections of the Act at some point in the organizational drive, that is, to have committed unfair labor practices proscribed by either or both section 8(a)(1) and section 8(a)(3). In all four cases, the employer was found by the Board, additionally, to have refused to bargain collectively with the representative of his employees in violation of section $8(a)(5)$.

Where the four individual cases essentially differed, then, was in (a) the extent to which section 9 election procedures were utilized and (b) the precise type of retaliatory and illegal response brought into action by the employer. As to the latter, the Court treated the reliance upon the constitutional guarantee of free speech in Sinclair separately and at some length. The seemingly endless debate as to when speech becomes coercion rather than the protected expression of views and opinions, however, is not directly relevant to the questions under analysis herein and will not be the subject of the discussion which follows. As to the former, it is difficult to quarrel with the Court's conclusion that basic rules as to required recognition could be formulated and made applicable to all four situations whether or not

28395 U.S. at 580 .

29157 N.L.R.B. 1065 (1966).

30166 N.L.R.B. 186 (1967) and 166 N.L.R.B. 674 (1967).

81166 N.L.R.B. 636 (1967).

32164 N.L.R.B. 261 (1967). 
an election had been actually sought or held in a particular dispute. In each of the four cases two vital considerations existed: first, a finding by the Board that unfair labor practices on the part of the employer had been committed during the organizational campaign; second, a finding by the Board that, at some point in time during the organizational campaign, the union had secured "authorization cards" from a majority of employees within the bargaining unit designating it as the employee's exclusive bargaining representative. These two findings, their validity and their impact, furnished the requisite foundation for the Court's overview of the entire field of non-election recognition rules.

The Fourth Gircuit refused to enforce the orders to bargain entered by the Board in Gissel, Heck's and General Steel; the First Circuit sustained such an order to bargain in Sinclair. ${ }^{33}$ The disparate conclusions reached by those circuits essentially hinged upon their differences as to the validity of authorization cards as a measure of employee choice, the Fourth Circuit finding such indicia of support inherently unreliable and the First Circuit, in company with other circuits, ${ }^{34}$ reaching the opposite conclusion. Having found that the status of exclusive representative could be obtained, under the Act, by means other than a section 9 election, Chief Justice Warren devoted much of the remainder of the opinion in Gissel to an analysis of the disparate views of the circuit courts as to the values and evils of the authorization card based claim for recognition. Perhaps because, prior to Gissel, the debate as to that topic among practitioners, commentators, Board members and judges had been so heated, the Court's basic agreement with the Board and the First Circuit could (and very presumably has) misled employers, unions and their counsel into a belief that much more was settled by the decision than is the fact. The Court's action in Gissel, as a careful reading of its text will make clear, left far more questions open than settled. Analysis of that text, indeed, leaves an observer with the feeling that there may have been a loud judicial "thud" registered on the upper floors of the legal establishment on June 16, 1969, but that we must, warily, await the falling of the second shoe.

33 See note 27 supra.

34 The Second, Fifth, Sixth and Eighth Gircuits all had prior to Gissel specifically rejected the Fourth Circuit's conclusions on authorization cards. NLRB v. United Mineral \& Chemical Corp., 391 F.2d 829 n.10 (2d Cir. 1968); NLRB v. Goodyear Tire \& Rubber Co. Retread Plant, 394 F.2d 711, 712-3 (5th Cir. 1968); NLRB v. Atco-Surgical Supports, Inc., 394 F.2d 659, 660 (6th Cir. 1968); NLRB v. Ozark Motor Lines, 403 F.2d 356 (8th Cir. 1969). 


\section{Gissel: The Decided and the Undecided Issues}

In the terminology of the classics, 'Tissel presented the Court with a Rubicon which, like Caesar, it could either ford or merely survey as to possible future crossings. The violent (at least in verbiage and in depth of conviction) dispute which underlay the cases before it was made explicit in the wholly disparate conclusions reached by the First and Fourth Circuits. It is no criticism of the Court to state that it chose not to be a Caesar. This is, perhaps, best illustrated by a short summary of the net result obtained in Gissel. Sinclair, where the Board order was enforced by the First Circuit, was affirmed. The remaining three cases were remanded to the Board for further action. The difference in disposition was founded upon the specific findings made by the Board in each of the four cases. This difference is critical to an understanding of how little Gissel may have actually settled. The Court noted that the Board in Sinclair found specifically that "the employer's threats of reprisal were so coercive that, even in the absence of a $\S 8(\mathrm{a})(5)$ violation, a bargaining order would have been necessary to repair the unlawful effect of those threats." 35 The Court found this finding valid and sufficient to sustain the First Circuit's enforcement order. In the remaining three cases, Gissel, Heck's and General Steel, in the words of the Court, "the Board did not make a similar finding that a bargaining order would have been necessary in the absence of an unlawful refusal to bargain."36

In sum, the Court chose to rest disposition of the four cases upon a determination of the breadth of Board remedial power. While it initially phrased the issue as "the propriety of a bargaining order as a remedy for a $\S 8(a)(5)$ refusal to bargain"37 where employer actions have made a section 9 election either impossible or invalid, the Court's disposition of that issue leaned heavily upon a determination of the propriety of such an order as a remedy for pervasive and extensive non-section $8(a)(5)$ violations. The Court thus stated:

Before considering whether the bargaining orders were appropriately entered in these cases, we should summarize the factors that go into such a determination. Despite our reversal of the Fourth Gircuit ... on all major issues, the actual area of disagreement between our position here and that of the Fourth Circuit is not large as a practical matter. While re-

35395 U.S. at 615.

38 Id. at 615-6.

37 Id. at 610 . 
fusing to validate the general use of a bargaining order in reliance on cards, the Fourth Circuit nevertheless left open the possibility of imposing a bargaining order, without need of inquiry into majority status on the basis of cards or otherwise, in "exceptional" cases marked by "outrageous" and "pervasive" unfair labor practices. Such an order would be an appropriate remedy for those practices, the court noted, if they are of "such a nature that their coercive effects cannot be eliminated by the application of traditional remedies, with the result that a fair and reliable election cannot be had."38

Further, the Court noted that "[t]he Board itself . . . has long had a similar policy of issuing a bargaining order, in the absence of $a$ $\S 8(a)(5)$ violation or even a bargaining demand, when that was the only available, effective remedy for substantial unfair labor practices."39 The limits of the Court's survey and approval of these positions are best summarized in its own words:

The only effect of our holding here is to approve the Board's use of the bargaining order in less extraordinary cases marked by less pervasive practices which nonetheless still have the tendency to undermine majority strength and impede the election processes. ${ }^{40}$

What differentiated this second category of cases in which a bargaining order was authorized, however, lay in the Court's further statement that, as to this group, the Board must make an additional finding, that is, "that at one point the union had a majority."41 In sum, the foundation of the bargaining order in the first group rested upon the requirement of an effective deterrent to employer misconduct; in the second, upon "effectuating ascertainable employee free choice" where an election cannot be utilized for such purposes. ${ }^{42}$

Upon establishing the foregoing, the Court concluded that a third category of situations existed-those in which there had been "minor or less extensive unfair labor practices, which, because of their minimal impact on the election machinery, will not sustain a bargaining order." 43

To summarize, the Court in Gissel affirmed that an order to bargain could be appropriate in a section $8(a)(5)$ case, absent a section 9 elec-

38 Id. at $613-4$.

39 Id. at 614 (emphasis added).

$40 \mathrm{Id}$.

$41 \mathrm{Id}$.

42 Id.

$43 \mathrm{Id}$. at 615 . 
tion, if there were a combination of (a) unfair labor practices of less dimensions than would, of themselves, justify such an order as a deterrent to employer misbehavior, (b) but of sufficient impact to make a fair election improbable and, (c) a demonstration of majority support at some point which could be established by union authorization cards.

What the Court did not decide is not only implied in the above review but was made explicit in the text of the opinion itself. Thus, the Court advised that '[ $[\mathrm{b}]$ ecause the employers' refusal to bargain in each of these cases was accompanied by independent unfair labor practices which tend to preclude the holding of a fair election, we need not decide whether a bargaining order is ever appropriate in cases where there is no interference with the election process." 44 In what well may become known as the "famous footnote eighteen," it further explicated the areas of non-decision:

18. In dealing with the reliability of cards, we should reemphasize what issues we are not confronting. As pointed out above, we are not here faced with a situation where an employer, with "good" or "bad" subjective motivation, has rejected a card-based bargaining request without good reason and has insisted that the Union go to an election while at the same time refraining from committing unfair labor practices that would tend to disturb the "laboratory conditions" of that election. We thus need not decide whether, absent election interference by an employer's unfair labor practices, he may obtain an election only if he petitions for one himself ; whether, if he does not, he must bargain with a card majority if the Union chooses not to seek an election; and whether, in the latter situation, he is bound by the Board's ultimate determination of the card results regardless of his earlier good faith doubts, or whether he can still insist on a Union-sought election if he makes an affirmative showing of his positive reasons for believing there is a representation dispute. In short, a union's right to rely on cards as a freely interchangeable substitute for elections where there has been no election interference is not put in issue here; we need only decide whether the cards are reliable enough to support a bargaining order where a fair election probably could not have been held, or where an election that was held was in fact set aside. ${ }^{45}$

The breadth and depth of the Rubicon thus left uncrossed deserves emphasis. Gissel, both in direct and indirect fashion, made it clear that

44 Id. at 595 (emphasis added).

$45 \mathrm{Id}$. at $601 \mathrm{n} .18$. 
the Court was approving Board-compelled bargaining sans election only in instances where recourse to a ballot under section 9 was made impossible by employer misconduct. It left untouched by any judicial toe that far shore where an election could have been held or was held without employer interference. As to such instances, footnote eighteen goes to some length, literally, in disclaiming any present determination by the Court as to the legal obligations, if any, imposed by section $8(a)(5)$ on an employer who is confronted with a majority claim which is not followed, either on his motion or on that of the claimant union, by an attempt to use the machinery of section 9 . It is as to these unanswered questions, and the place of motive, measured by the employer's "good faith" or "bad faith" in their solution, that the remainder of this paper is directed.

\section{Gissel: The Options LeFT OPEN}

The situation posed by the judicial reticence epitomized by footnote eighteen can perhaps best be illustrated by a summary of the options confronting an employer faced with a possible demand for recognition by a union engaged in organizing his employees. The first option open to such an employer is, of course, to do absolutely nothing in the way of influencing his employees as to the choice of a collective bargaining representative and to await a demand for recognition. ${ }^{46}$ If the demand never arrives and no charge of a refusal to bargain is made, he has no legal problems and his collection of union organizing leaflets can be filed and forgotten. Secondly, if the demand arrives together with a claim of majority support based on authorization or membership cards, the employer can accord recognition. That option, of course, is one which will, normally, appeal only to the employer whose general reaction to unionization is either favorable or neutral. Its exercise, moreover, is accompanied by the possibility that, unwittingly or not, he will violate the mandate of Bernhard-Altmann by recognizing a union which does not, in fact, have the majority support which it claims. ${ }^{47}$ Assuming that our hypothetical employer is reluctant to run the risks posed by Bernhard-Altmann, but does not otherwise feel strongly on the subject of unionization, a further option is open. Such an employer is legally

46 The term "absolutely nothing" must be accorded its fullest meaning. As will be discussed hereinafter, even conduct not constituting an unfair labor practice may be sufficient to alter the employer's legal position.

47 International Ladies' Garment Workers (Bernhard-Altmann Texas Corp.) v. NLRB, 366 U.S. 731 (1961), still remains the caveat that an innocent mistake which installs a minority union as exclusive bargaining representative constitutes a violation of employee rights guaranteed by $\S 7$ of the Act and remains such a violation even though the union, after recognition, achieves that majority endorsement by the employees. 
entitled to file a petition under section $9(\mathrm{c})(1)(B)$ which will result in a relatively quick determination, under government auspices, of the question of whether or not a majority of his employees have designated a given union as their exclusive representative. The time required for such a secret ballot election is so relatively brief (as contrasted with the processing of a charge of violation of section 8(a)(5)) that even the most litigious union is likely to be tempted to accept selection of this option and its results, assuming, of course, that the employer remains in a neutral or relatively noncombative stance in the period prior to the election. ${ }^{48}$

Those are, of course, the "easy" cases. Indeed, each of the above situations almost subsumes a presence of "good faith" 'or, at least, the absence of antipathy to the union on the part of the affected employer. As true of most of the "easy" cases in law, their existence (in uncounted and unascertainable numbers) offers little guidance to solution of the "hard" cases. The "hard" cases, of course, arise from the complex of fact patterns which can and do develop if an employer views the possible advent of a union on his premises with a range of reaction extending from unarticulated distaste not translated into action to the opposite extreme of active and coercive attempts to keep the union out. In such cases, the question of "motive" can easily be raised as an operative factor in application of the Act's strictures to employer action. "Motive" or "intent," however, as the authors of this paper have previously observed as to other sections of the statute, ${ }^{49}$ are terms which evade easy definition or application in the area of unfair labor practices. As a thoughtful and perceptive management lawyer not long ago observed, it is a logical premise that "most employers do not want unions in their plants and this attitude is neither irrational nor unlawful." matic matter, accordingly, we can assume that a request for recognition will normally be met with less than enthusiastic response. Obviously this negative response is not of and by itself unlawful. It does, on the other hand, easily provoke an examination of a type of "motive," that is, "good faith" or "bad faith" as a relevant factor in the resolution of cases involving rejection of a recognition demand.

With this in mind, let us return to the options in the "hard" cases.

48 Union acknowledgement of this comparatively speedy avenue of ascertaining employee desires was accentuated, indeed, in Gissel, by the contention made there (and left undisposed by the Court) that an employer must file his own petition rather than await filing by the claimant labor organization "whereby the election can be subjected to considerable delay." 395 U.S. at 595.

49 See note 1 supra.

/ 50 Barbash, Authorization Card Problems and Their Cure, 22 N.Y.U. ANN. Conf. LAB. 143 (1969). 
Although not discussed in detail above, Gissel approved, under certain restrictions, one form of immediate employer response to a request for recognition. That response is an employer poll conducted under various limitations and protections. As the Court put it in Gissel, "the Board's recent cases indicate that reasonable polling in this regard will not always be termed violative of $\S 8(a)(1)$ if conducted in accordance with the requirements set out in Struknes Construction Co." "в1 The criteria for a lawful poll under Struknes are:

Absent unusual circumstances, the polling of employees by an employer will be violative of $\S 8(a)(1)$ of the Act unless the following safeguards are observed: (1) the purpose of the poll is to determine the truth of a union's claim of a majority, (2) this purpose is communicated to the employees, (3) assurances against reprisal are given, (4) the employees are polled by secret ballot, and (5) the employer has not engaged in unfair labor practices or otherwise created a coercive atmosphere. ${ }^{52}$

They are stringent enough so that the cautious comment of the Court that such a poll "will not always be termed" a violation of the Act seems well advised in its less than certain acceptance of the private poll as a lawful option.

A further option, obviously, is to commence a campaign designed to convince the affected employees that their best interests lie in rejection rather than acceptance of an exclusive collective bargaining representative. That option incorporates a host of subsidiary possibilities. First, an employer campaign that includes action violative of section 8 of the National Labor Relations Act. The Court, in Gissel, held that the Board, under such circumstances, must determine whether or not these unfair labor practices make "the holding of a fair election unlikely" or so "undermined a union's majority" as to cause an election to be set aside. ${ }^{53}$ The second possibility is an employer campaign which does not

51395 U.S. at 609.

52 Struknes Constr. Co., 165 N.L.R.B. 1062 (1967). In justification for these limits the Board stated:

The purpose of the polling in these circumstances is clearly relevant to an issue raised by a union's claim for recognition and is therefore lawful. The requirement that the lawful purpose be communicated to the employees, along with assurances against reprisal, is designed to allay any fear of discrimination which might otherwise arise from the polling, and any tendency to interfere with employees' Section 7 rights. Secrecy of the ballot will give further assurance that reprisals cannot be taken against employees because the views of each individual will not be known. And the absence of employer unfair labor practices or other conduct creating a coercive atmosphere will serve as a further warranty to the employees that the poll does not have some unlawful object, contrary to the lawful purpose stated by the employer.

165 N.L.R.B. at 1063.

53395 U.S. at 610 . 
include the commission of unfair labor practices but which, under the doctrine of General Shoe, ${ }^{54}$ nonetheless furnishes grounds upon which the Board will invalidate an election result rejecting the union. As discussed above, the Court in Gissel avoided any determination of the impact of that class of employer activity upon the duty to bargain. ${ }^{55}$ The third possibility is an employer campaign which does not constitute either an unfair labor practice or conduct which will be held to invalidate an election but which is successful enough in eroding union strength so as to cause the union to withdraw its petition and file a refusal to bargain charge. Again, in Gissel, the Court refrained from any firm indication of what its position would be; conversely, the Court's approach subsumed an approval of the Board's holding in Irving Air Chute ${ }^{56}$ that a union which loses a section 9 election and cannot successfully maintain that employer conduct invalidated those results is estopped from entering a claim that the duty to bargain, nonetheless, existed at a date prior to the election. ${ }^{57}$

All such possibilities exist, at least in theory. All are, however, very possibly subject to limitations which could arise if the organizing union exercises certain options open to it. The first of these and, perhaps, the one as to which most legal uncertainty attaches, is a union demand for recognition founded on evidence other than the much disputed autho-

54 General Shoe Corp., 77 N.L.R.B. 124 (1948). Here the Board set aside the election upon finding that although the employer's activities preceding the election did not constitute unfair labor practices within the meaning of the Act, the impact of the employer's activities was such as to "raise substantial doubt as to whether the results of the election reflect the employees' free choice of a collective bargaining representative." Id. at 127 .

55 It should be noted, in this regard, that the Court nonetheless repeatedly refers to an election being made impossible because of "unfair labor practices." See, e.g., the Court's reference to current Board practice as sustaining that "the key to the issuance of a bargaining order is the commission of serious unfair labor practices that interfere with the election processes." 395 U.S. at 594 (emphasis added), and the Court's definition of the issue before it as "the propriety of a bargaining order as a remedy for a $\$ 8(\mathrm{a})(5)$ refusal to bargain where an employer has committed independent unfair labor practices." Id. at 610 (emphasis added). By contrast, the Court treats with the effectiveness of "re run" elections as a remedy without distinguishing whether or not the "re run" was the result of invalidation of an election because of unfair labor practices or conduct of a lesser degree condemned under the General Shoe doctrine. See, particularly, id. at $611 \mathrm{nn} .30$ \& 31.

56 Irving Air Chute Co., 149 N.L.R.B. 627 (1964), enforced, 350 F.2d 176 (2d Cir. 1965).

57 As with so many other issues discussed herein, the Court did not directly touch on the limit which Irving Air Chute imposed upon the freedom accorded by Bernel Foam as to usage of both the electoral and the unfair labor practice route to recognition. However, the Court did summarize the holding of Bernel Foam as stating "there is nothing inconsistent in the Union's filing an election petition and thereby agreeing that a question of representation exists, and then filing a refusal-to-bargain charge after the election is lost because of the employer's unfair labor practices." 395 U.S. 575, $615 \mathrm{n} .34$ (1969) (emphasis added). 
rization card. Thus, particularly in a small unit where the logistics are much more favorable, a union may base its demand for recognition upon an open demonstration-such as a picket line or strike-of more than majority support. As to this union option, Gissel is silent except as to quotation of the current Board position that "an employer could not refuse to bargain [even absent an election] if he knew, through a personal poll for instance, that a majority of his employees supported the union." 58 The second union action (or, in this instance, more properly inaction) which could vitally affect the employer's legal position would be the simple refusal on the part of the union to make use of the election process of section 9 and, instead, to rely solely upon a legal obligation to recognize founded upon section 8(a)(5). Not only is this a practical possibility, it is, indeed, one which is inevitable for a union claiming attainment of majority support at a time when the provisions of section 9 make the holding of an election impossible. ${ }^{59}$

The possibility of this approach cannot be said to have been unconsidered by the Court. As the Court acknowledged:

The Union argues here that an employer's right to insist on an election in the absence of unfair labor practices should be more circumscribed, and a union's right to rely on cards correspondingly more expanded, than the Board would have us rule. The Union's contention is that an employer, when confronted with a hard-based bargaining demand, can insist on an election only by filing the election petition himself immediately under $\S 9(\mathrm{c})(1)(B)$ and not by insisting that the Union file the election petition, whereby the election can be subjected to considerable delay. If the employer does not himself petition for an election, the Union argues, he must recognize the Union regardless of his good or bad faith and regardless of his other unfair labor practices, and should be ordered to bargain if the cards were in fact validly obtained. And if this Court should continue to utilize the good faith doubt rule, the Union contends that at the least we should put the burden on the employer to make an affirmative showing of his reasons for entertaining such doubt. ${ }^{60}$

$58 I d$. at 594 (emphasis in original). The Board position as stated by the Court also posited an exception when an employer shifted the basis for his refusal to recognize from a question as to appropriate unit to a doubt as to union strength. Id.

59 This would occur when, for example, $\S 9(c)(3)$ prohibits the holding of a second election in a twelve month period during which the union secures majority support demonstrated by authorization cards. See Conren, Inc. v. NLRB, 368 F.2d 173 (7th Cir. 1966), cert. denied, 386 U.S. 974 (1967).

60395 U.S. at $594-5$ (emphasis added). 
On this issue, as set forth in the emphasized portion above, the Court specifically refused to rule, noting, as has been observed previously, that in the context of the cases before it, it "need not decide whether a bargaining order is ever appropriate in cases where there is no interference with the election processes."61

\section{Post Gissel: Does Motrve Still Matter?}

In dealing with these options and counter-options, the continued or discontinued place of motive- "the 'good faith' doubt rule" referred to in the union argument just quoted-cannot be ignored. The Court specifically acknowledged that "[u]nder the Board's current practice, an employer's good faith doubt is largely irrelevant, and the key to the issuance of a bargaining order is the commission of serious unfair labor practices that interfere with the election processes and tend to preclude the holding of a fair election."'62 In its opinion in Heck's, Inc., on remand from the Court, the Board observed that it understood Gissel to mean that "refusal-to-bargain violations may no longer be predicated upon an employer's subjective motivation when confronted by a Union's demand for recognition, i.e., his good or. bad faith concerning the Union's majority status." 63 Nonetheless, careful scrutiny of the text of Gissel fails to disclose a firm conclusion by the Court as to whether "good faith" in recognition disputes, indeed, is a dead issue at law rather than temporarily interred as a matter of "current practice."

The reason is not difficult to determine. For some thirty-five years it has been almost a commonplace in federal labor law that if a union claims to represent a majority of the employees in a unit appropriate for purposes of collective bargaining and the employer has no "good faith" doubt as to the existence of that majority, denial of recognition constitutes a violation of the duty to bargain contained in section $8(a)(5) .{ }^{64}$ Testing whether or not, in fact, such a "good faith" doubt

61 Id. at 595 .

62 Id. at 594 .

63180 N.L.R.B. No. 82, 73 L.R.R.M. $1099-1100$ (1970). Similarly, in Triggs-Miner Corp., 180 N.L.R.B. No. 39, 73 L.R.R.M. 1085 (1969), the Board rejected the trial examiner's finding that the employer did not have a "good faith doubt" when it rejected the union's demand for recognition, stating that it is the "peryasive or aggravated character" of the employer activities that justifies the issuance of a bargaining order, not the presence or absence of the employer's "good faith doubt." See also Mechanical Specialties Co. v. NLRB, 414 F.2d 898, 900-1 (9th Cir. 1969); Arcoa Corp., 180 N.L.R.B. No. 5, 73 L.R.R.M. 1034 (1969); NLRB v. Wylie Mfg. Co., 417 F.2d 192, 195-6 (10th Cir. 1969); W. T. Grant Co., 180 N.L.R.B. No 45, 73 L.R.R.M. 1047 (1969); Central Soya of Canton, 180 N.L.R.B. No. 86, 73 L.R.R.M. 1069 (1970).

64 As summarized in an excellent report by the Committee on Labor and Social Security of the Association of the Bar of the City of New York: 
exists so as to justify denial of immediate recognition has been, nonetheless, a matter which has consistently troubled the Board and the courts. As we have previously observed, it is, after all, a fair surmise that most employers do not look upon the advent of a union with wild glee; he will hope for time and opportunity to dissuade his personnel from that choice unless, that is, in the classic terms of Joseph Barbash, "he embraces the union either as a sweetheart or as a Sabine Woman relaxed because rape is inevitable." 65 It is also a fair surmise that, in the sophistication of the present era, it will be a rare employer who openly announces that no evidence of union support will induce him to accord recognition. ${ }^{66}$ Operating under these practical considerations, it is small wonder that the Board and the courts have wandered and stumbled as to how and in what manner the undisclosed state of mind can be translated into a legal finding of "good" or "bad" faith.

Prior to Gissel, at least, the Board approach in inquiry into motivation in any given case was heavily affected by two considerations. First, was the demand for recognition demonstrated by open, physically apparent support for the union (a picket line or strike) or one supported by more questionable or debatable forms of union support, that is, an authorization card? Second, was the employer's rejection of the demand for recognition accompanied by other expressions of anti-union animus, either lawful or unlawful? ${ }^{67}$ Gissel focuses only upon those situations

It has long been Board law, generally approved by the Courts, that an employer is guilty of an unlawful refusal to bargain, in violation of Section $8(a)(5)$ of the National Labor Relations Act, and will therefore be required to recognize a union as the representative of his employees if:

(I) a majority of the employees in an appropriate unit have signed valid cards authorizing the union to represent them;

(2) the union asks the employer to bargain with it on behalf of those employees and he refuses to do so; and

(3) the employer at the time of the refusal lacks a "good faith doubt" that the union then represents a majority of the employees.

Bargaining Orders in the Absence of or Contrary to the Results of an NLRB Election, 24 RECORD of N.Y.C.B.A. 101 (1969).

65 Barbash, supra note 50.

66 That predicate must be modified to the following extent. In Textile Workers v. Darlington Mfg. Co., 380 U.S. 263 (1965), the Court, by footnote, indicated that an employer might state, if such were actually the fact, that the advent of unionization would result in permanent closure of the enterprise and the opportunity for employment. Id. at $274 \mathrm{n} .20$. Such a statement of "fact" (as contrasted with threat or prediction without substantiation) is one whose practical impact is still unplumbed as to usage or effectiveness.

67 These conclusions, in the authors' judgment, are implicit in the Board's pre-Gissel decisions. They are, nevertheless, difficult to document. As to the first, it should be observed that while stray decisions may exist as to the different legal situations occupied by employers confronted with a direct, physical and open display of support (as in the case of a picket line) and those only presented with a written expression of support (as in the case of authorization cards), the Board has never, to our knowledge, explicated any view as to when, in this spectrum of types of union support, recognition must be con- 
involving (a) authorization card demands for recognition and (b) serious employer attempts to disrupt the possibility of a choice being registered by the affected employees in a Board election. The Board and Court disposition of these particular types of refusal to bargain cases should not, however, cloud the fact that they are special types and that the issue of "good faith" has broader application as to required recognition in other situations.

As the Court emphasized, even in the special area of authorization card based demands, the Board approach has varied over the years. The Court identified three separate "phases" through which Board policy proceeded: the Joy Silk doctrine, ${ }^{88}$ the amended version of that doctrine as pronounced in Aaron Brothers, ${ }^{69}$ and a new delineation born in the course of oral argument before the Court in Gissel. ${ }^{70}$ In phase one, Joy Silk, an authorization card based demand could be lawfully rejected if the employer did so in "good faith." But the Board:

... could find a lack of good faith doubt and enter a bargaining order in one of two ways. It could find (1) that the employer's independent unfair labor practices were evidence of bad faith, showing that the employer was seeking time to dissipate the union's majority. Or the Board could find (2) that the employer had come forward with no reasons for entertaining any doubt and therefore that he must have rejected the bargaining demand in bad faith. ${ }^{71}$

sidered a legal fait accompli allowing no opportunity for negative response or when it is one which allows a legally supportable "doubt." As to the second conclusion, the Court noted in Gissel that the "traditional approach" of the Board had been that it could find an absence of "good faith" and the requisite foundation for a bargaining order in either independent unfair labor practices "showing that the employer was seeking time to dissipate the union's majority" or a failure by the employer to come forward with any legitimate reasons for rejecting the bargaining demand. 395 U.S. 575, $592-3$ (1969). See text accompanying notes $68 \& 69$ infra.

68 Joy Silk Mills, Inc., 85 N.L.R.B. 1263 (1949), enforced, 185 F.2d 732 (D.C. Cir. 1950).

69 Aaron Bros. Co., 158 N.L.R.B. 1077 (1966). The Board there held that the General Counsel must establish the employer's lack of good faith and that this was crucial to the determination of the legality of the refusal to bargain. As the Board stated: "Absent an affirmative showing of bad faith, an employer, presented with a majority card showing and a bargaining request, will not be held to have violated his bargaining obligation under the law simply because he refuses to rely upon cards, rather than an election, as the method for determining the union's majority." Id. at 1078.

70395 U.S. at 594.

$71 I d$. at 592-3. The Court cited Snow \& Sons, 134 N.L.R.B. 709 (1961), enforced, 308 F.2d 687 (9th Cir. 1962) as an example of this phase of Board law where the employer rejected the findings of an impartial card check and insisted that the union proceed to an election with the end result that the Board issued a bargaining order stating that the employer's refusal to bargain was "without a valid ground therefor." 134 N.L.R.B. 709, 710-1 (1961). 
In phase two, Joy Silk, as thus described, was modified in Aaron Brothers where the burden of proof of bad faith was "shifted" to the Board's General Counsel. In accomplishing this:

Two significant consequences were emphasized. The Board noted (1) that not every unfair labor practice would automatically result in a finding of bad faith ... [but] only if the unfair labor practice was serious enough to have the tendency to dissipate the union's majority. The Board noted (2) that an employer no longer needed to come forward with reasons for rejecting a bargaining demand. The Board pointed out, however, that a bargaining order would issue if it could prove that an employer's "course of conduct" gave indications as to the employer's bad faith. ${ }^{72}$

In phase three,

[T]he Board announced at oral argument that it had virtually abandoned the Joy Silk doctrine altogether. Under the Board's current practice, an employer's good faith doubt is largely irrelevant, and the key to the issuance of a bargaining order is the commission of serious unfair labor practices that interfere with the election processes and tend to preclude the holding of a fair election. Thus, an employer can insist that a union go to an election, regardless of his. subjective motivation, so long as he is not guilty of misconduct; he need give no affirmative reasons for rejecting a recognition request, and he can demand an election with a simple "no comment" to the union. ${ }^{73}$

The caveat was added, however, that knowledge by the employer of the union's majority or a shift from a defense of "inappropriate unit" to an afterthought of doubt of majority would not be measured by the same non-motivational slide rule. ${ }^{74}$

Reading-and rereading-of these passages leaves the observer with complete frustration as to what, in fact, Gissel posits as the present or future role of motivation in bargaining demand cases. The Board, it is true, advised the Court that motivation was "largely irrelevant" and the Court, in its disposition of the four cases, at no point indicated that it felt the Board was reading the statute wrong in that regard. The term "largely irrelevant," however, is one which, in any linguistic race for certainty of meaning, is an entry that would be left at the starting gate. The Court almost deliberately, it would seem, refrained from

72395 U.S. at 593-4.

73 Id. at 594 (emphasis added).

74 Id. 
either defining the term or indicating that it would support or reject an entirely contrary view of motivation if such were to be adopted by the Board in the future. To deepen the confusion, of course, the previously adverted to "famous fcctnote eighteen" is a virtual litany of litigation in which motivation might or might not be dispositive and as to which the Court offers no prediction of eventual resolution. It is to these aspects of the general applicability, if any, of motivation to the entire gamut of recognition cases under section $8(a)(5)$ that the remainder of this discussion is directed.

\section{Employer "Motive" in Regognition Demands: What Gissel Could Forecast}

Gissel, then, for all its length and complexity, treated only a slice of a segment of a far larger problem. Its net result was to identify two situations in which a bargaining order is justified absent establishment of a union majority by a section 9 election. The first of those situations is where the employer commits unfair labor practices so "outrageous" and "pervasive" that their coercive effects cannot be removed without use of that remedy. The Court implied approval of installation of an exclusive bargaining representative in such situations even "in the absence of a $\S 8(a)(5)$ violation or even a bargaining demand" when this is "the only available, effective remedy for substantial unfair labor practices."75 To that category of cases, Gissel adds a second-that is, where there are less pervasive practices "which nonetheless still have the tendency to undermine majority strength and impede the election processes." But, as to this second category, the Court requires "a showing that at one point the Union had a majority."76 Impliedly, it posits that a demand for recognition is made and rejected. It further adds an instruction to the Board that, even in this category, the agency must determine whether a section 9 election is, pragmatically, unavailable because of the impact of the employer misconduct.

In the first of the above categories, the bargaining order is clearly identified as a "deterrent" to further employer unlawful action whatever the choice of the affected employees might be. In the second, the bargaining order is justified as being the only available method of ascertaining employee choice as to a bargaining representative. Employer motivation in either category is ignored as irrelevant, at least so far as any formal Board finding on that question. It is, of course, obvious that the serious quality of the employer unfair labor practices involved in

75 Id. at 614 .

76 Id. 
either category would lead any reasonable individual to conclude that the employer deeply desired to keep the union out of his plant whether or not his employees desired to keep the union out of his plant and whether or not his employees desired to be represented by it. To put it mildly, such serious unfair labor practices would almost invariably provide a more than adequate basis for a Board finding that the employer's basic motive was to frustrate the principle of collective bargaining; or, more bluntly, such a motivation is so subsumed in the types of anti-union actions dealt with in the two aforementioned categories as to make a separate finding to that effect not only "boiler plate" but a legal formality without the slightest justification.

When these conclusions are placed in conjunction with Chief Justice Warren's lengthy recital of what was not being decided in Gissel, it is clear that no one can accurately state whether "motive" in recognition refusal cases retains any legal significance or is merely the inconsequential parent of acts which, of themselves, may or may not constitute statutory violations. If, however, Gissel fails to determine that vital question, it does contain some clues as to what the answers may eventually be.

As has been observed above, "motive" is a term of many meanings. In recognition demand cases, it is more commonly referred to under the label of "good faith" or "bad faith" in the refusal to recognize. Neither section $8(a)(5)$ nor section $8(b)(3)$ of the present Act uses the terms "good" or "bad" faith. ${ }^{77}$ Both track the language of section $8(5)$ of the original Wagner Act. When the latter statute became law in 1935, we can safely assume that the Congress assumed that the advent of unionization in a particular enterprise would be accompanied either by a debatable claim of majority support to be tested in a section 9 election or by a demonstration of "convincing support." This "convincing support," as Gissel noted, ${ }^{78}$ might be made clear by a strike or by a vote to strike. In this simplistic approach, the union would either have the obvious backing of a majority or merely the claim of one. The key was, in the words of the Court in United Mine Workers, the "absence of any bona fide dispute as to the existence of the required majority."79 Whether or not a "bona fide dispute" existed understandably can be and was transmuted into the question of

77 See notes 6 \& 7 supra.

78 "Almost from the inception of the Act . . . it was recognized that a union did not have to be certified as the winner of a Board election to invoke a bargaining obligation; it could establish majority status by other means under the unfair labor practice provision of $\S 8(a)(5)-b y$ showing convincing support, for instance, by a union-called strike or strike vote . . . 395 U.S. at 596-7 (emphasis added).

79 United Mine Workers v. Arkansas Flooring Co., 351 U.S. 62, 69 (1956). 
whether a "good faith doubt" of majority status was held by the employer. Thus was born "motive" as an operative factor in determining the legality of rejections of recognition demands.

It is not only pertinent but essential to ask, however, whether the presence of a "bona fide dispute" hinges upon the existence of a good faith doubt upon the part of the employer as to the union's majority support. More directly, does determination of the existence of a "bona fide dispute" require examination of the employer's state of mind? Three illustrations may serve to prove the point. The first was furnished by Senator Taft during the debates on the 1947 amendments:

Today an employer is faced with this situation. A man comes into his office and says, "I represent your employees. Sign this agreement, or we strike tomorrow" ... The employer has no way in which to determine whether this man really does represent his employees or does not. The bill gives him the right to go to the Board ... and say, "I want an election. I want to know who is the bargaining agent for my employees." 80

The second illustration is one drawn from cases determined at a time when the Board was thrashing its way toward the position announced in oral argument before the Court in Gissel.81 In this situation, the employer is confronted with a bargaining demand supported by submission of signed authorization cards from a majority of employees in the appropriate unit. The employer asks for time to consult his attorney and never, subsequently, contacts the union. In the interim he, presumably (or perhaps provably), has an opportunity to examine the cards but never questions their authenticity.

The third illustration is one suggested by a pre-Gissel study of this area by a committee of the Association of the Bar of the City of New York. ${ }^{82}$ In this situation, the employer is presented with a bargaining demand based upon authorization cards and states to the union:

You have the cards now, and I can't say there is anything wrong with them-but my employees do not have any infor-

8093 Cong. REc. 3838 (1947) quoted by the Court in Gissel, 395 U.S. at 599-600 n.16.

81 See, e.g., John P. Serpa, Inc., I55 N.L.R.B. 99 (1965), rev'd, Retail Clerks, Local No. 1179 v. NLRB, 376 F.2d 186 (9th Cir. 1967). The Board's original refusal to issue a bargaining order was reversed by the Ninth Circuit which stated that: "[W] then the employer makes his own examination of the authorization cards and is convinced of their identity and validity ...., a subsequent refusal to recognize the union is adequate affirmative evidence of a lack of good faith doubt as to majority status." 376 F.2d at 190. The Board acquiesced and subsequently issued the bargaining order. 166 N.L.R.B. 396 (1967).

8224 RECORD OF N.Y.C.B.A. 101, 103 (1969). 
mation on the other side, and I believe I could persuade them to vote against you in a secret ballot election if $I$ am permitted to have an opportunity to campaign against you to the extent permitted by law.

It is one thing to determine that all, some or none of these employer responses satisfy the law; it is quite a different matter to do so in the context of the examination of the "good faith" of the employer in each.

We can assume, indeed, that if any of these three employers were questioned in the privileged confines of the confessional, he would acknowledge that he found the idea of a union in his plant distasteful. We can assume, further, that in each of the three cases the employer has no evidence at hand to disprove the contention of the union that a majority of his employees have designated the union as their exclusive representative. Absent any other asssumptions or evidence of additional acts on the part of the employer, we submit that on the standard of a "bona fide dispute," no violation of the provisions of section 8(a)(5) would appear to be established-at least in the limited factual context of the illustrations. This is a valid conclusion, of course, if the term "bona fide dispute" is reduced to its essentials-does an employer question whether a majority of his employees, given a considered choice, would require him to deal with a labor organization as their exclusive representative. By contrast, if the standard of "good faith doubt" is utilized, all three employers may have committed a violation of the section; whether they have done so will be dependent upon a further examination of their states of mind. That examination must necessarily raise issues of the burden and quantum of proof necessary to resolve it.

The difficulties inherent in the transmutation of "bona fide dispute" into an inquiry into motive were not immediately apparent as long as the Board adhered to the so-called Aiello doctrine. ${ }^{83}$ Under Aiello, a union was required to exercise either the option of a section 9 election or a charge of unlawful refusal to bargain under section 8(a) (5). A union, accordingly, was forced to make a choice on the basis of what, normally, would be very pragmatic considerations. Given a clear and convincing showing of support by employees but facing both a denial of recognition and a presumably virulent campaign against it, the section $8(a)(5)$ option would hold attractions despite the length of time required to secure an enforceable order to bargain through unfair labor practice procedures. Given a less clear showing of support

83 Aiello Dairy Farms, 110 N.L.R.B. 1365 (1954). The "Hobson's choice" created by Aiello was expressly overruled by the Board in Bernel Foam Prods. Co., 146 N.L.R.B. 1277 (1964). 
and the possibility of a successful election campaign, the section 9 option would be attractive. Where, under Aiello, a union chose the first option of an $8(a)(5)$ charge, the probabilities were heavily weighted that the same evidence which would establish absence of a "bona fide dispute" would also establish absence of "good faith" in the denial of the recognition request.

The Aiello doctrine, during the period of its existence, was accompanied by and inextricably intertwined with a second doctrine, Joy Silk. ${ }^{84}$ As summarized by the Court in Gissel, Joy Silk was relied upon by the Board as authority to enter a bargaining order without an election if (a) "the employer's independent unfair labor practices were evidence of bad faith, showing that the employer [in denying the recognition request] was seeking time to dissipate the union's majority," or (b) "the employer had come forward with no reasons for entertaining, any doubt [of majority status] and therefore . . . must have rejected the bargaining demand in bad faith." 85 It is of central importance to an understanding of the problem to recognize that, so long as a union making a bargaining demand under Aiello was required to opt between an election and a section 8(a)(5) order, Joy Silk had only limited application. It was utilized, indeed, where the election route to recognition was deliberately discarded by the union.

The problem, indeed, did not really surface in full degree until, as has been noted, in 1964 the Board rejected the conclusion that there either was a "bona fide dispute" to be determined by an election or there was no such dispute and the union's majority status was so unequivocally established as to obviate the need for an election. ${ }^{86}$ Bernel Foam predicated exactly the opposite premise; a union may consider that it has conclusively established its majority position and still, as a formal matter, file a petition for an election to establish that fact via a more expeditious route. Bernel Foam further, as a prior analysis has aptly put the matter, concluded that:

... the election and section $8(a)(5)$ proceedings determine different issues of fact; an election determines the union's support on the date of the election, while the section 8(a)(5) refusal-to-recognize charge determines support on the date of the employer's refusal to bargain. ${ }^{87}$

Once that dichotomy was recognized as valid, that is, that a union

84 Joy Silk Mills, Inc., 85 N.L.R.B. 1263 (1949), enforced, 185 F.2d 732 (D.C. Cir. 1950). 85895 U.S. at 592-3.

86 Bernel Foam Prods. Co., 146 N.L.R.B. 1277 (1964).

87 Comment, Refusal-to-Recognize Charges Under Section 8(a)(5) of the NLRA: Card Checks and Employee Free Choice, 33 U. GHr. L. REv. 387, 403 (1966). 
majority extant on the date when the request for bargaining was made could be legally recognized despite the absence of a union majority on another date when an election was held and lost because of employer conduct, it became critical to determine whether existence of a "bona fide doubt" on the earlier date was distinguishable from the existence of "good faith" during the pre-election campaign.

To illustrate, Senator 'Taft's hypothetical employer in the first situation recited above alleged the existence of a "bona fide dispute" as to whether the union at his doorstep truly represented a majority of his employees. Under Aiello, if the union then resorted to section 9 procedures for obtaining recognition, the question of whether the employer hated unions or the degree to which he was inclined to take action to prevent unionization became irrelevant except to the extent his conduct distorted the results of the subsequent election. Those factors ceased to be critical in determining the legality of his action at the moment of the declination of recognition. Conversely, if the union filed a section 8(a)(5) charge, the Joy Silk approach was available. Under that approach, not only was the existence of a "bona fide dispute" challengeable because of the absence of any reasonable basis for disbelieving the union claim, but any employer independent unfair labor practices could be used to sustain the inference of a belief in such a majority and a desire to gain time to erode it.

Under Bernel Foam a far broader inquiry into motive was posited. Loss of an election by the union (whether because of unfair labor practices on the part of the employer or by conduct short of section 8 violations which disturbed the "laboratory conditions") triggered a re-examination of employer motivation at the time of the original request for recognition. The difference may appear to be subtle but it is critical. Bernel Foam, in net impact, made employer conduct during the course of an election campaign not only a factor in reassessing what the employer state of mind was at the time of the original refusal to bargain but, in addition, a cause for such re-examination-a vastly expanded area of examination and judgment.

We may presume that it was at least tacit recognition of this broader expanse of inquiry and the problems inherent therein which caused the Board to engage in the successive modifications of Joy Silk related in Gissel. ${ }^{88}$ First, in Aaron Brothers, the burden of proof, in at least its initial posture, was clearly placed upon the General Counsel to show, after the election route had been chosen and the ballot resulted in a loss for the union, that it was "bad faith" which caused the 
original rejection of recognition. ${ }^{89}$ Aaron Brothers, in the Court's view at least, recorded a Board acknowledgement that (a) not every unfair labor practice committed by the employer after denial of recognition could, retrospectively, be shown to evidence an original act of bad faith in that denial and (b) that the employer was under no necessity of affirmatively proving "good faith" in that denial..90 The further modification, accomplished in oral argument before the Court in Gissel, was that "an employer's good faith doubt is largely irrelevant" and that "the key to the issuance of a bargaining order is the commission of serious unfair labor practices that interfere with the election processes and tend to preclude the holding of a fair election." "01

If the measure thus announced by the Board in oral argument is accepted, none of the three employers in the illustrations given above could, absent other facts, be found to be in violation of section 8(a)(5) because of their denial of recognition-unless, indeed, one turns to the as yet unfathomed depth of the two exceptions to the above principles reserved by the Board, that is, "knowledge" of the existence of a majority or a change of position from rejection of the recognition request because of technical questions (the appropriate unit) to rejection based on a doubt of majority strength.

The Board gives ground only grudgingly-and probably properly so in view of its position as the protector of public rights. If the two exceptions noted-"knowledge" of majority status or change in position presumably connoting an original absence of bad faith-are utilized to any degree by the Board, the statement that the employer's "good faith doubt is largely irrelevant" in recognition rejection cases is saved from the charge of ingenuousness only by stressing the inclusion of the adjective "largely" in the above quotation. Thus, the employer, as in the third situation set forth above, who states frankly that he does not doubt the existence of present majority support but does doubt the continuance of that majority support if tested after he has had an opportunity to present his case is in deep difficulty. By his own statement, he can be held to have had "knowledge" of the fact that his employees, at the point in time of the demand for recognition, were supporting the union. If the Board's exception is given full rein, it makes the preceding statement in Gissel that "an employer can insist that a union go to an election, regardless of his subjective motivation, so long as he is not guilty of misconduct" 02 either empty

89158 N.L.R.B. 1077 (1966).

90395 U.S. at 593.

91 Id. at 594.

92 Id. 
of meaning or an invitation to duplicity. The employer in the third illustration would be in violation of the Act-or escape its sanctions-solely on the basis of his willingness to state candidly his full and honest assessment of the situation. Silence, followed by exposition of his views that unionization would be unwise, would satisfy the law. Candor, followed by the same exposition, would be the grounds for a successful section 8(a)(5) charge.

It is interesting to note that the Court's recital of the Board's "current practice," as discussed above, is immediately followed in Gissel by a review of what the union litigants there would have considered a proper exposition of the law-a review which also, in essence, seeks to avoid the problems that inevitably arise when "motivation" is made the lodestone of what is lawful under the Act: "if this Court should continue to utilize the good faith doubt rule, the Union contends that at the least we should put the burden on the employer to make an affirmative showing of his reasons for entertaining such doubt."93

We have, then, the Board's current "Gestalt" as to required recognition; a Gestalt which hinges upon a pattern of employer action making required recognition either necessary as a deterrent to continuance of illegal conduct (and enjoyment of the fruits thereof) or the only possible (if questionable) method of ascertaining employee choice as to selection of an exclusive bargaining representative. We have, also, the Board's unplumbed exceptions which inherently retain at least a remnant of inquiry into motive as a facet of the pattern of conduct found illegal_ "knowledge" of a majority status or change in legal grounds for opposition to recognition. Both these inescapably posit some degree of a test of motive. By contrast, the union position set forth immediately above would establish a new Gestalt, free from any burden of proof of motive: a demand for recognition based upon authorization cards could not be rejected unless the employer affirmatively takes action to resolve the issue of representation by a Boardconducted secret ballot election. This Gestalt avoids the issue of motive by assuming its existence or non-existence on an almost per se basis. He who has a good faith doubt illustrates it by filing a petition; he who does not is condemned forthwith. As a backstop, the union position contends that, at a minimum, the burden of proof of motive should be placed upon the employer.

The Court, as we have observed, succeeded in Gissel in avoiding any flat rejection of inquiry into motive in required recognition cases contenting itself with approval of the Board's "current" position in 
the limited context of the cases before it and specifically reserving decision on the questions which remain. Yet there are portions of the opinion which could be read as forecasting the Court's view when, as must occur, the unresolved issues are again before it. In particular, the Court's view of the proper range of administrative inquiry into motivation as to employee designation of a bargaining agent-the signing of an authorization card-may well incorporate an exposition of basic principles which could, equally, apply to the undetermined issues. Reading the entrails of a Supreme Court decision for omens of the future is as hazardous a task as any Roman priestess assumed; it is also, then and now, an operation impelled at least in part by the legitimate concerns of those affected by what the future has in store.

As has been observed above, much of the broad import of the Gissel decision has been obscured because of its extended discussion of a source of major, extended controversy-the legal effect to be accorded an employee signature to a card designating a union as his or her collective bargaining representative. The circuit courts of appeal were dramatically divided on that issue. ${ }^{94}$ The Court's determinationwhile limited to so-called "single purpose" cards-was unequivocal; an employee should be considered bound by the language of his authorization. As summarized by the Court:

The objections to the use of cards voiced by the employers and the Fourth Circuit boil down to two contentions: (1) that, as contrasted with the election procedure, the cards cannot accurately reflect an employee's wishes, either because an employer has not had a chance to present his views and thus a chance to insure that the employee choice was an informed one, or because the choice was the result of group pressures and not individual decision made in the privacy of a voting booth; and (2) that quite apart from the election comparison, the cards are too often obtained through misrepresentation and coercion which compound the cards' inherent inferiority to the election process. ${ }^{95}$

The Court's answer to these contentions was blunt:

Neither contention is persuasive, and each proves too much. The Board itself has recognized, and continues to do so here, that secret elections are generally the most satisfactory-indeed the preferred-method of ascertaining whether a union has majority support. The acknowledged superiority of the election process, however, does not mean that cards are 
thereby rendered totally invalid, for where an employer engages in conduct disruptive of the election process, cards may be the most effective-perhaps the only-way of assuring employee cheice. As for misrepresentation, in any specific case of alleged irregularity in the solicitation of the cards, the proper course is to apply the Board's customary standards ... and rule that there was no majority if the standards - were not satisfied. ${ }^{96}$

In expanding on this theme, the Court noted that "We would be closing our eyes to obvious difficulties, of course, if we did not recognize that there have been abuses, primarily arising out of misrepresentations by union organizers as to whether the effect of signing a card was to designate the union to represent the employee . . . or merely to authorize it to seek an election to determine that issue." 97 In this regard, the Court paid particular attention to what has become known as the Cumberland Shoe ${ }^{98}$ doctrine: "if the card itself is unambiguous (i.e., states on its face that the signer authorizes the Union, to represent the employee for collective bargaining purposes and not to seek an election), it will be counted [as to determination of majority status] unless it is proved that the employee was told that the card was to be used solely for the purpose of obtaining an election." 98 The Court subsequently, in Gissel, characterized this doctrine as "expressly" avoiding inquiry into "the subjective intent of each signer."100 It further noted that Cumberland, in this regard, had received a mixed reaction from the circuit courts. ${ }^{101}$ The Court concluded (but only as to single purpose cards) that "employees should be bound by the clear language of what they sign unless that language is deliberately and clearly canceled by a union adherent with words calculated to direct the signer to disregard and forget the language above his signature"102 and that " $[w]$ e therefore reject any rule that requires a probe of an employee's subjective motivations as involving an endless and unreliable inquiry."'103

$96 I d$. at 602-3 (emphasis added).

97 Id. at 604 .

98 Cumberland Shoe Corp., 144 N.L.R.B. 1268 (1963), enforced, 351 F.2d 917 (6th Cir. 1965). See also Levi Strauss \& Co., 172 N.L.R.B. No. 57, 70 L.R.R.M. 1566 (1968); WinnDixie Stores, Inc., 166 N.L.R.B. 227 (1967); International Union, UAW v. NLRB (Preston Prods. Co.), 373 F.2d 671 (D.C. Cir. 1967). But see NLRB v. S.E. Nichols Co., 380 F.2d 438 (2d Cir. 1967); NLRB v. Swan Super Cleaners, Inc., 384 F.2d 609 (6th Cir. 1967).

99395 U.S. at 584.

100 Id. at 605.

101 Id.

$102 I d$. at 606.

$103 \mathrm{Id}$. at 608. 
If is quite easy to understand the Court's blunt rejection of what had become increasingly urgent pressure by the circuit courts upon the Board to conduct hearings and inquiries as to what George Paycheck really felt when Joe Biceps, the union organizer, said "sign here." A review of the cases, their almost incredible variation in factual situations and the legal maneuvering by counsel confronted with the problem of accumulating sworn testimony-months after the fact -of a state of mind which accompanied an action, all powerfully support the logic of the Court's distaste. There is every possibility, as the Court acknowledges, that holding the employee to the plain, written meaning of the document he signed will, in some instances, bind him to a choice he may not have consciously made-at least with any feeling of its full legal import. The alternatives, however, are quite plainly worse.

It is significant, further, that the Court specifically restricted its ruling to the so-called single purpose card: "nothing we say here indicates our approval of the Cumberland Shoe rule when applied to ambiguous, dual-purpose cards."104 It is only speculation, but the logic of the Court's approach would appear to negate in the dual purpose card situation either inquiry into motivation or use of such a card for establishment of a majority status. Thus, the Court's reliance upon and acceptance of the unambiguous authorization (without inquiry into motivation) must be viewed in the limited terms of the situation posited by Gissel, that is, where the employer has made a secret ballot election unavailable by actions in violation of the statute. The Court's discussion of the use of cards was presented in the framework of their reliability "where an employer engages in conduct disruptive of the election process." 105 It is one thing to state that cards of unambiguous statement are, regrettably, the only way of possibly ascertaining employee desires in such a situation. It is a giant step further down the road to state that ambiguous cards should be regarded as a lawfully sufficient measure of employee support even in identical circumstances of employer opposition. The essence of the second category of situations in which an order to bargain sans election was approved in Gissel was that "employee sentiment once expressed through cards would, on balance, be better protected by a bargaining order"106 than by an election. Holding an employee to the flat and unambiguous delegation of authority which he has signed (without attempted examination of knowledge or motivation at the time of signature) is 
supportable on the ground that his written commitment is preferable to a subsequent examination under courtroom conditions. In the instance of the dual purpose card, however, use of the card for purposes of establishing majority status would require either (a) binding the employee to one interpretation of an admittedly ambiguous written statement or (b) subjecting him to an examination under oath at a subsequent time in a process which the Court characterized, properly, as "an endless and unreliable inquiry." 107 The text of Gissel, in our opinion, simply does not sustain a forecast that the Court will resort to such a fruitless inquiry into employee motivation in the dual purpose card situation after stressing the logic and limitations which must attend use of the single purpose card in place of an election.

If the foregoing is correct, the Court has, for all practical purposes, ${ }^{108}$ completely discarded inquiry into motivation insofar as employee signatures upon authorization cards are concerned. The question immediately arises as to why this discarding of examination of intent should not be equally applicable to all questions of recognition. Gissel teaches that the "fact" of employee choice of a collective bargaining representative can and sometimes must be legally established without a test of the state of mind and intentions actually registered. The "fact" of lawful or non-lawful refusal to recognize on the part of the employer would seem to be equally establishable without reference to motive and with the same advantage of avoidance of fruitless inquiry into the state of mind of the actor. The various positions espoused in Gissel go far, indeed, toward acceptance of that end result. The Board conceded that an "employer's good faith doubt is largely irrelevant." 109 The unions then conceded that a "recognize us or file a petition" requirement would be far preferable to any inquiry as to subjective motivation. 110 The Court accepted exclusion of examination of the motivation of the parties as the proper result in a broad spectrum of representational disputes. The time would seem to have arrived for a final disposition of the remnants of this element of "intent" which has been, now, so largely excluded from consideration by those concerned in so wide a spectrum of representational disputes. The issue must be faced, in sum, whether there is any legal excuse for retention of "motive" in any Gestalt of recognitional controversies.

107 Id. at 608 .

108 The Court did caution against "a too easy mechanical application of the Cumberland rule" by the Board. Id. at 608. The precise meaning of the caveat is not made clear by the Court.

109 Id. at 594.

110 Id. at $594-5$. 


\section{Post-Gissel-The BoARd Response}

In the three cases remanded by the Supreme Court in the disposition of Gissel, the Board, upon what appears to be a cursory review of the trial examiners' findings, reaffirmed, without deviation from the strict language of the Court's two categories of non-motive cases, each of the original bargaining orders. ${ }^{111}$ The remand in Heck's, in fact, required three separate affirmations of the Board's previous analyses of the various fact patterns all of which resulted in a parroting of the Gissel standards. ${ }^{112}$ In each of the three basic cases, the Board concluded, in the words of the Supreme Court, that the employer activities involved were "so coercive that, even in the absence of a $\S 8(a)(5)$ violation, a bargaining order would have been necessary to repair the unlawful effect of those threats." 113 The Board also expressly rejected its previous findings as to the presence or absence of the respective employers' good faith doubt, concluding that the Court's rulings in Gissel precluded any investigation or even conjecture of the employer's subjective motivation in support of a refusal-to-bargain charge. This transformation in the Board's approach is evident in its ultimate conclusion in General Steel:

[W] reaffirm our earlier conclusion that the Respondent violated Section 8(a)(5), not because Respondent lacked a good-faith doubt as to the Union's majority status when it refused the Union's bargaining request, but because of its refusal to bargain with the Union while engaging in its campaign of unfair labor practices to undermine the Union's support among its employees. ${ }^{114}$

The Board's basic approach to post-Gissel refusal-to-bargain cases, whether on remand or of first instance, has been similarly rigid-almost a "knee jerk" reaction-in its adoption of the Court's linguistic delineations if not the principles enunciated therein.

In the aftermath of Gissel, the Board has, in fact, when in doubt "played trump." A review of these cases indicates that the Board has attempted no real demarcation between the Court's two categories of employer response to a demand for recognition that will warrant a

111 Heck's, Inc., 181 N.L.R.B. No. 129, 73 L.R.R.M. 1524 (1970); Heck's, Inc., 180 N.L.R.B. No. 82, 73 L.R.R.M. 1099 (1970); Heck's, Inc., 180 N.L.R.B. No. 64, 73 L.R.R.M. 1030 (1969); General Steel Prods., Inc., 180 N.L.R.B. No. 8, 72 L.R.R.M. 1579 (1969); Gissel Packing Co., 180 N.L.R.B. No. 7, 72 L.R.R.M. 1571 (1969).

112 See note 111 supra.

113180 N.L.R.B. No. 8, 72 L.R.R.M. at 1580.

114 Id. 
bargaining order. 115 The Board has instead tended to merge the Court's criteria for both categories, adding in some cases the ultimate footnote that in any event the employer conduct was so pervasive and coercive as to warrant a bargaining order even in the absence of an $8(a)(5)$ violation. ${ }^{116}$ As viewed by the Board, its obligation in cases of this nature is "to apply the test set forth in the Court's opinion to the unfair labor practices found"117 in light of the totality of the circumstances. 118 At present, the Board's articulated responses to the Court's tests simply do not provide any sure basis for determining when and under what circumstances a bargaining order will be granted.

To the extent that Gissel has had any real impact on the Board's approach to this type of case, the instances where the Board has dismissed a refusal-to-bargain charge and denied a union request for a bargaining order are most informative. ${ }^{119}$ Thus, in Blade-Tribune Publishing Co., ${ }^{120}$ on remand the Board specifically overruled its previous section 8(a)(5) finding stating that a review of the facts in light of the Court's standards demonstrated that the employer's violations fell within the category of "minor or less extensive unfair labor practices which, because of their minimal impact on the election machinery, will not sustain a bargaining order."121 The Board dismissed the refusal-to-bargain allegations "notwithstanding ... . [its] earlier finding

115 American Door Co., 181 N.L.R.B. No. 11, 73 L.R.R.M. 1305 (1970); J. H. Rutter-Rex Mfg. Co., 180 N.L.R.B. No. 133, 73 L.R.R.M. 1164 (1970); West Side Plymouth Inc., 180 N.L.R.B. No. 68, 73 L.R.R.M. 1014 (1969); Triggs-Miner Corp., 180 N.L.R.B. No. 39, 73 L.R.R.M. 1085 (1969); Atlanta Daily World, 179 N.L.R.B. No. 166, 73 L.R.R.M. 1407 (1969); Interstate Equipment Co., 179 N.L.R.B. No. 167, 72 L.R.R.M. 1567 (1969); Vaca Valley Bus Lines, 179 N.L.R.B. No. 107, 72 L.R.R.M. 1425 (1969); S.E. Nichols-Dover, Inc., 179 N.L.R.B. No. 44, 72 L.R.R.M. 1311 (1969); Texaco, Inc., 178 N.L.R.B. No. 72,72 L.R.R.M. 1146 (1969); Arrow Specialties, Inc., 177 N.L.R.B. No. 92, 72 L.R.R.M. 1025 (1969).

116 Henry Colder Co., 181 N.L.R.B. No. 58, 73 L.R.R.M. 1367 (1970); Atlas Engine Works, Inc., 181 N.L.R.B. No. 13, 73 L.R.R.M. 1276 (1970); Louisburg Sportswear Co., 180 N.L.R.B. No. 114, 73 L.R.R.M. 1141 (1970); W. T. Grant Co., 180 N.L.R.B. No. 45,73 L.R.R.M. 1047 (1969); Hancock Fabric Outlet, Inc., 179 N.L.R.B. No. 108, 72 L.R.R.M. 1432 (1969); Hy-Vee Food Stores, Inc., 178 N.L.R.B. No. 101, 72 L.R.R.M. 1190 (1969).

117 C \& G Electric, 180 N.L.R.B. No. 52, 73 L.R.R.M. 1041, 1042 n.2 (1969), in which the Board specifically rejected the employer's contention that the General Counsel must affirmatively show that a secret ballot election cannot be held.

118 W. T. Grant Co., 180 N.L.R.B. No. 45, 73 L.R.R.M. 1047, 1049 (1969).

119 J. A. Conley Co., 181 N.L.R.B. No. 20, 73 L.R.R.M. 1301 (1970); Central Soya of Canton, 180 N.L.R.B. No. 86, 73 L.R.R.M. 1069 (1970); Blade-Tribune Publishing Co., 180 N.L.R.B. No. 56, 73 L.R.R.M. 1041 (1969); Stoutco, Inc., 180 N.L.R.B. No. 11, 73 L.R.R.M. 1107 (1969); Arcoa Corp., 180 N.L.R.B. No. 5, 73 L.R.R.M. 1034 (1969); Seymour Transfer, Inc., 179 N.L.R.B. No. 5, 72 L.R.R.M. 1306 (1969).

120180 N.L.R.B. No. 56, 73 L.R.R.M. 1041 (1969).

$121 I d$. 
that the Respondent acted in bad faith in refusing to bargain with the Union ....".122 Likewise, in Central Soya of Canton, ${ }^{123}$ the Board considered that the "relatively minor" quality of the employer's unfair labor practices, the "erasure" of their effect and the absence of any indication that a coercion-free re-run election could not be held were sufficient to dismiss the section 8(a)(5) allegations.

The Board, accordingly, "playing trump," appears well set upon a course of action in which employer stances and actions taken in response to a union organizing campaign will be slotted into the three categories designated by the Court in Gissel. The magic words are spoken and formal inquiry into motive is specifically disavowed. The Board has not squarely stated what the remaining import, if any, is of the two exceptions to the irrelevancy of good faith in recognition cases, that is, "knowledge" of a majority at the time the request for recognition is made and change of reason as to rejection of a bargaining request.

\section{CoNCLUSION}

In a pre-Gissel survey (cited therein) of employer refusals to recognize unions, a highly qualified commentator observed that the Board was approaching a state of acknowledgement "that the significance of unfair labor practices [committed in campaigning against the union] lies less in their retroactive impact on the substantive lawfulness of the insistence on an election than in their effect on the appropriate remedy when an election has been set aside or aborted."124 The Board, nonetheless, in Gissel still left open at least a door to the possibility that the substantive lawfulness of the recognition rejection could be based upon an examination of motive, that is, the exceptions noted immediately above. The Court not only did not comment on these exceptions in any direct fashion but specifically, in footnote eighteen, left open the possibility that "good faith" might still be brought to bear upon the issue of whether, in denying a request for recognition, the employer exhibited a state of mind which rejected "the collective bargaining principle" or evidenced design to gain time to undermine a present "majority."125 Professor Lesnick's additional comments, in the survey cited above, as to that approach bear reiteration:

I must confess to a total inability to understand in what sense relevant here an employer is obliged to accept the collective

123180 N.L.R.B. No. 86, 73 L.R.R.M. 1069 (1970).

124 Lesnick, Establishment of Bargaining Rights Without an NLRB Election, 65 Micr.

L. REv. 851, 855 (1967).

125395 U.S. at 601 n.18. 
bargaining principle. Of course he is enjoined to bargain in good faith (when he is obliged to bargain at all), and he must refrain from discrimination or coercion affecting employee attitudes toward collective bargaining. But what has that got to do with his state of mind or motivation when it comes to his response to an initial demand for recognition? It certainly cannot be unlawful for him to want to defeat the union at the polls and thereby obtain a lawful ground for rejecting collective bargaining. If an employer is to be permitted, first, to insist on an election, and then to campaign against the union in that election, it is perfectly clear that he is being permitted to reject the collective bargaining principle so long as his employees do not, by voting for the union, oblige him to accept it. It simply encourages hypocrisy to permit an employer to acknowledge his doubts, but not his hopes.

Similarly, the notion that an employer may not deny recognition "in order to gain time during which to undermine the union's majority" is an unfortunate one. If taken seriously, it would result in deeming it irrelevant whether the employer's opposition to unionization took lawful or unlawful form, and regarding as critical the question whether the employer was seeking to dissipate an existing majority or to prevent the union from obtaining one. Yet precisely the reverse situation seems to prevail. The Board has explicitly declined to rely on lawful anti-union conduct as a ground for inferring that an initial refusal to recognize was unlawful. But the taking of this step, unless no more than obeisance to the language of section $8(c)$, implies that a legitimate purpose of the election is not simply to ascertain the validity of the union's initial claim to represent a majority, but also to test the durability of that majority in the crucible of a pre-election campaign. Once that fact is acknowledged, it seems obvious that it is entirely irrelevant to the legitimacy of the employer's conduct whether the union initially commanded a majority, which it hoped to hold through a campaign, or began with something less than fifty per cent support, which it hoped to augment. ${ }^{126}$

Indeed, support for the latter portion of this analysis would seem to be implicit in the Board's repeated efforts to assure a greater and still greater measure of "informed" employee choice after full and reasoned discussion of the issues in representational campaigns. ${ }^{127}$

128 Lesnick, supra note 124, at 858-9.

127 Thus, in the process of requiring that both parties, union and employer, have access to employees during organizational drives, the Board held in Excelsior Underwear, Inc., 156 N.L.R.B. 1236, 1240 (1966): 
Gissel, in sum, established a Gestalt of required recognition and one in which motive-at least insofar as the necessity for separate inquiry-plays no part. It is difficult to believe that the Court was being more than properly cautious-deciding no more than it was required to decide-in the language it employed in footnote eighteen of Gissel. It is even more difficult to believe that the Court, therein, seriously intended to lay the basis for future findings that where a secret ballot election is possible, upon demand of either party, or is held under "laboratory conditions," the decision registered by such an electoral process can be made subservient to what it so aptly characterized as an "endless and unreliable inquiry."

The considerations that impel us to adopt the foregoing rule are these: "The control of the election proceeding, and the determination of the steps necessary to conduct that election fairly [are] matters which Congress entrusted to the Board alone." In discharging that trust, we regard it as the Board's function to conduct elections in which employees have the opportunity to cast their ballots for or against representation under circumstances that are free not only from interference, restraint, or coercion violative of the Act, but also from other elements that prevent or impede a free and reasoned choice. Among the factors that undoubtedly tend to impede such a choice is a lack of information with respect to one of the choices available. In other words, an employee who has had an effective opportunity to hear the arguments concerning representation is in a better position to make a more fully informed and reasonable choice. (Emphasis added.) 